\title{
The effect of soya protein supplement enriched with three amino acids on duodenal flow of soluble nitrogen fractions and amino acids in dairy cows*
}

\author{
L. Kř̌̌žová ${ }^{1,3}$, M. Richter ${ }^{1}$, J. Třináctý ${ }^{1}$, J. Šterc ${ }^{2}$ and S. Hadrová ${ }^{1}$ \\ ${ }^{1}$ Research Institute for Cattle Breeding, Ltd., Department Pohořelice \\ Vídeňská 699, 69123 Pohořelice, Czech Republic \\ ${ }^{2}$ University of Veterinary and Pharmaceutical Sciences \\ Brno, Czech Republic
}

(Received 20 June 2006; revised version 11 June 2007; accepted 6 September 2007)

\begin{abstract}
The aim of this study was to confirm the presumption that the duodenal flow of soluble nitrogen fractions: soluble non-ammonia nitrogen (SNAN), soluble protein and long-chain peptides nitrogen (SPLPN), soluble short-chain peptides and free amino acids nitrogen (SSPFAAN) and free amino acids (FAA) will be increased after the application of ruminally protected tablets containing soya protein and amino acids (Met, Lys, His). Control animals received the same mixture but in ruminally non-protected (powder) form. The experiment was carried out on three lactating Holstein cows of average weight of $523 \mathrm{~kg}$ fitted with ruminal and duodenal cannulas. The experiment was divided into 4 periods of $14 \mathrm{~d}(10 \mathrm{~d}$ preliminary period and a 4 -d experimental period). In the first period one cow received the tablets $(\mathrm{T})$ and the other two received the powder $(\mathrm{C})$ with the same composition. In the subsequent period the rate of animals was antipodal. Cows were fed on diet based on maize silage, lucerne hay and a supplemental mixture. Powder or tablets consisted of purified soya-protein HP 300, Lys, Met and His. The experimental treatment did not significantly $(\mathrm{P}>0.05)$ influence duodenal flow of SNAN, SPLPN and SSPFAAN. In case of FAA significant $(\mathrm{P}<0.05)$ increase of flow (in g/day) was obtained in T group for Met (1.25 vs 0.35), Lys (2.07 vs 0.76 ), His (2.13 vs 0.49 ) and $\operatorname{Arg}(0.37$ vs 0.15$)$ against the control C.
\end{abstract}

KEY WORDS: dairy cows, duodenum, soluble nitrogen fractions, free amino acids

\footnotetext{
${ }^{*}$ Supported by the MSM 2678846201 and GAČR 523/02/0164

${ }^{3}$ Corresponding author: e-mail: Ludmila.S@seznam.cz
} 


\section{INTRODUCTION}

The INRA Protein System (Jarrige, 1989) classifies proteins present in feedstuffs into three principal categories based on the study of Ørskov and McDonald (1979). Category A is water-soluble and can be completely degraded in the rumen. Category B is water insoluble but potentially degradable in the rumen and the degree of its degradation is dependent on the flow rate of digesta and category $\mathrm{C}$ is completely rumen non-degradable. A highly sophisticated Cornell System (Russel et al., 1992) uses a chemical method for this fractionation and classifies feed protein into five groups: $\mathrm{A}, \mathrm{B}_{1}, \mathrm{~B}_{2}, \mathrm{~B}_{3}$ and $\mathrm{C}$. Fractions $\mathrm{A}$ and $\mathrm{B}_{1}$ are buffersoluble, i. e. degradable in the rumen (Sniffen et al., 1992). This system considers soluble nitrogen fractions as completely rumen-degradable as well. However, recent data indicate that the soluble $\mathrm{N}$-fractions are not degraded at the same rate and that due to their high flow rate the liquid fractions of the digesta can get out of a complete degradation in the rumen. Volden et al. (1998) mentioned that approximately $20 \%$ of intraruminally applied free amino acids can escape from the rumen. In an experiment with grass and grass silage eluates it was found out that on average $11.2 \%$ of small peptides (with less than 10 amino acid molecules) and $5 \%$ of free amino acids were not degraded in the rumen (Volden et al., 2002). These fractions contribute to the total amount of protein digestible in intestines (PDI) due to a good availability of soluble protein in the small intestine.

Nevertheless, the ruminal degradability of soluble nitrogen fractions is high (i. e. more than $80 \%$ ) and the application of rumen non-protected amino acids and protein concentrates would be uneconomical. The ruminal protection can assure that these important nutritional substances will be transported into the small intestine with only minimal losses.

The aim of this study was to demonstrate that the flow of soluble $\mathrm{N}$-fractions and free amino acids through the duodenum increases after the addition of a ruminally protected soya protein enriched with Met, Lys and His in comparison with non-protected form.

\section{MATERIAL AND METHODS}

\section{Animals and procedures}

The present experiment is an extension of a previous study (Třináctý et al., 2006) in which three lactating dairy cows were used in the experiment to study the effect of administration of soya-protein enriched with three amino acids (Met, Lys and His) in two forms - either rumen protected or unprotected, added to rumen. 
Three lactating Holstein cows (1.-3. lactation, 17.-35. week of lactation) weighing on average $523 \mathrm{~kg}$ were fitted with ruminal and duodenal cannulas. The experiment was divided into 4 periods. Each period (14 d) consisted of 10 $\mathrm{d}$ preliminary period and a 4-d experimental period. In the first period one cow received the tablets ( $\mathrm{T}$ group) and the other two received the powder ( $\mathrm{C}$ group - control) with the same composition. In the subsequent period the rate of animals was antipodal so each animal received both variants in two replications.

Cows were fed individually twice daily (7.00 and $16.35 \mathrm{~h})$ ad libitum a mixed diet based on a maize silage (54.7\%), lucerne hay (15.0\%) and a supplemental mixture (30.3\%; composition mentioned in Třináctý et al., 2006). The supplement consisted of purified soya protein concentrate HP 300 enriched with amino acids (Met, Lys, His) in amounts calculated with regard to requirements of experimental animals (Rulquin et al., 2001a,b). The active substance of the supplement (it is, \%: purified soya protein concentrate HP 300 93.0, Met 2.4, Lys 1.6 and His 3.0) was mixed thoroughly with the tablet additives (binding materials, modifiers of specific gravity, etc.). The homogenized mass was divided into two parts: control (C) that stayed in this powder form and experimental (T) which was tableted and subsequently enwrapped with a protective layer. As the protective layer a biologically active mixture based on the vinyl-pyridine-styrene copolymer according to patent (Ardaillon et al., 1989) was used. This protective layer is stable at $\mathrm{pH}>5$ and is dissolved at $\mathrm{pH}<3.5$, so the tablets were considered to be rumenprotected. During the whole experimental period paper boluses containing either tablets or powder plus $7.5 \mathrm{~g}$ of chromium oxide which was used as a marker of digesta passage were placed into the rumen bottom of each dairy cow through the ruminal cannula twice daily before feeding. The applied amounts of the purified soya bean protein HP 300 and amino acids are presented in Table 1.

Duodenal chymus $(500 \mathrm{ml})$ was sampled from each animal in six-h intervals during the whole four-day experimental period starting on $7.00 \mathrm{a} . \mathrm{m}$. of the first day. On each subsequent day the time of sampling was postponed by $1.5 \mathrm{~h}$ so that the four-day experimental period represented a set of chymus samples obtained during the day in $1.5 \mathrm{~h}$ intervals (Schwab et al., 1992). The obtained samples were immediately frozen to $-20^{\circ} \mathrm{C}$.

Feed samples were taken on the third day of each experimental period and the feed refusals were collected and weighed prior to each feeding during the experimental period. These refusals were also kept frozen at $-20^{\circ} \mathrm{C}$. After the end of the experimental period samples collected from each dairy cow were pooled, homogenized and used for the preparation of a representative sample.

\section{Processing and analyses of chymus and feed samples}

Chymus samples obtained within a four-day experimental period were thawed and pooled for each dairy cow and each period. They were continuously 
stirred and used for the recovery of four average samples $(500 \mathrm{ml})$. Chymus samples were lyophilized while feed and feed refusals samples were dried at $55^{\circ} \mathrm{C}$ for $48 \mathrm{~h}$. After the equilibration of water content to laboratory humidity all samples were ground and sifted through a 1-mm screen. In feed and feed refusals samples dry matter (DM), ash (A), crude protein (CP), fat and crude fibre (CF).were estimated according to AOAC (1984). NDF (with $\alpha$-amylase) and ADF were estimated according to Van Soest et al. (1991). Content of $\mathrm{Cr}$ in samples of duodenal chymus were estimated according to Williams et al. (1962). In these samples, ammonia nitrogen was estimated in a water eluate ( $2 \mathrm{~g} / 100 \mathrm{ml}$ of distilled water) using a gas electrode (manufacturer Radelkis, Hungary). Total soluble nitrogen and soluble nitrogen after trichloroacetic acid precipitation were estimated using a modified method described by Licitra et al. (1996): buffer was replaced by distilled water and the samples were centrifuged at 27,000 $\mathrm{g}$ and $4^{\circ} \mathrm{C}$ due to an impaired filterability; nitrogen was estimated in the supernatant using the Kjeldahl method. In these samples, free amino acids (FAA) were estimated as well using the following method: $2 \mathrm{~g}$ of the sample were shaked for $30 \mathrm{~min}$ in $10 \mathrm{ml}$ of distilled water with a supplement of 5 $\mathrm{ml}$ of $10 \%$ sulphosalicylic acid. After the filtration the turbidity was removed by centrifugation at $10,000 \mathrm{~g}$ for $10 \mathrm{~min}$. Detectable free amino acids were estimated in an automatic analyser AAA 400 (Ingos, CR) using a Li citrate buffer system.

\section{Calculations}

Soluble non-ammonia nitrogen (SNAN), soluble protein and long-chain peptides nitrogen (SPLPN) and soluble short-chain peptides and free amino acids nitrogen (SSPFAAN) were calculated according the following equations:

$$
\text { SNAN }=\text { total soluble } \mathrm{N}-\text { ammonia } \mathrm{N}
$$

SSPFAAN $=$ soluble nitrogen after trichloroacetic acid precipitation - ammonia $\mathrm{N}$

$$
\mathrm{SPLPN}=\text { SNAN }- \text { SSPFAAN }
$$

The flow of DM through duodenum was calculated using the following formula:

DM flow $(\mathrm{kg} / \mathrm{d})=\mathrm{Cr}$ intake $(\mathrm{g} / \mathrm{d}) / \mathrm{Cr}$ concentration in chymus $(\mathrm{g} / \mathrm{kg} \mathrm{DM})$

The flow of all other nutrients (SNAN, SPLPN, SSPFAA and FAA) through duodenum was calculated using the formula:

Flow of SNAN, SPLPN, SSPFAA and FAA $(\mathrm{g} / \mathrm{d})=$ DM flow $(\mathrm{kg} / \mathrm{d}) \times$ concentrations of SNAN, SSPFAA and FAA in chymus $(\mathrm{g} / \mathrm{kg} \mathrm{DM})$. 


\section{Statistical analysis}

Statistical analysis of obtained data was performed using the GLM procedure from the statistic software SYSTAT 11.00.01 (USA). The following equation was used as a model for the comparison of concentrations and flows of nutrients in duodenum:

$$
\mathrm{Y}_{\mathrm{ij}}=\mu+\mathrm{T}_{\mathrm{i}}+\mathrm{C}_{\mathrm{j}}+\mathrm{T}_{\mathrm{i}} \mathrm{C}_{\mathrm{j}}+\varepsilon_{\mathrm{ij}}
$$

where: $\mu=$ total average, $T_{i}=$ effect of the experimental factors ( $\left.i=2\right), C_{i}=$ effect of the dairy cow $(j=3), \varepsilon_{i j}=$ residual error. Unbalanced numbers of animals in each period ( 1 vs 2) induced lost of degrees of freedom. From this reason the effect of period was propagated to the residual error.

\section{RESULTS}

The intake of individual components from tablets $(\mathrm{T})$ or powder $(\mathrm{C})$ was identical in both groups and is presented in Table 1.

Table 1. Consumption of supplemented components, g/day

\begin{tabular}{lrlr}
\hline Component & g/day & Component & g/day \\
\hline${\mathrm{HP} 300^{1}}^{1}$ & 306.00 & $\mathrm{TN}^{4}$ & 75.76 \\
$\mathrm{Met}^{2}$ & 8.80 & $\mathrm{TNAN}^{5}$ & 75.68 \\
$\mathrm{Lys}^{2}$ & 5.70 & $\mathrm{SNAN}^{6}$ & 50.28 \\
$\mathrm{His}^{2}$ & 10.60 & SPLPN $^{7}$ & 0.05 \\
$\mathrm{Arg}_{\mathrm{HP}}{ }^{3}$ & 0.63 & SSPFAAN $^{8}$ & 50.23 \\
Lys $_{\mathrm{HP}}{ }^{3}$ & 0.50 & & \\
\hline
\end{tabular}

${ }^{1}$ soya protein concentrate, ${ }^{2}$ added amino acids, ${ }^{3}$ free amino acids from HP $300,{ }^{4}$ total nitrogen, ${ }^{5}$ total non-ammonia nitrogen, ${ }^{6}$ soluble non-ammonia nitrogen, ${ }^{7}$ soluble protein and long-chain peptides nitrogen, ${ }^{8}$ soluble short-chain peptides and free amino acids nitrogen

The DM intake was significantly higher $(\mathrm{P}<0.05)$ for cows receiving rumenprotected tablets $(\mathrm{T}, 16.33 \mathrm{~kg} / \mathrm{d})$ than in the control group $(\mathrm{C}, 15.68 \mathrm{~kg} / \mathrm{d}$; Table 2). Increased DM intake was followed by increased consumption of other nutrients as presented in the previous article (Třináctý et al., 2006a). Average milk yield of the $\mathrm{T}$ group was higher $(17.80 \mathrm{~kg} / \mathrm{d} ; \mathrm{P}<0.05)$ than that of the control group $(16.73 \mathrm{~kg} / \mathrm{d})$. Milk yield expressed in 4\% FCM did not differ significantly $(\mathrm{P}>0.05)$ between treatments. Because of the differences in DM intake, milk yield and 4\% FCM were expressed in dry matter intake (Table 2) and they were not affected $(\mathrm{P}>0.05)$ by the treatment. 
Table 2. Dry matter intake and milk yield

\begin{tabular}{|c|c|c|c|c|c|c|}
\hline \multirow{3}{*}{ Item } & \multirow{3}{*}{ Unit } & \multirow{2}{*}{\multicolumn{2}{|c|}{$\begin{array}{c}C \\
n=24\end{array}$}} & \multirow{2}{*}{\multicolumn{2}{|c|}{$\begin{array}{c}\mathrm{T} \\
\mathrm{n}=24\end{array}$}} & \multirow{3}{*}{$\mathrm{P}$} \\
\hline & & & & & & \\
\hline & & mean & SEM & mean & SEM & \\
\hline Dry matter intake & $\mathrm{kg}$ & $15.68^{\mathrm{a}}$ & 0.325 & $16.33^{\mathrm{b}}$ & 0.265 & 0.032 \\
\hline Milk yield & $\mathrm{kg} / \mathrm{d}$ & $16.73^{\mathrm{a}}$ & 0.383 & $17.80^{\mathrm{b}}$ & 0.281 & 0.029 \\
\hline $4 \%$ FCM & $\mathrm{kg} / \mathrm{d}$ & 15.37 & 0.614 & 16.04 & 0.654 & 0.460 \\
\hline Milk yield/DM intake & $\mathrm{kg} / \mathrm{kg}$ & 1.08 & 0.034 & 1.09 & 0.021 & 0.675 \\
\hline FCM/DM intake & $\mathrm{kg} / \mathrm{kg}$ & 0.98 & 0.036 & 0.98 & 0.032 & 0.934 \\
\hline
\end{tabular}

${ }^{a, b}$ means in the same row followed by the different superscripts $\operatorname{differ}(\mathrm{P}<0.05)$

Flows of DM, nitrogen fractions and FAA through the duodenum are presented in Table 3. The DM flow through duodenum did not differ significantly $(\mathrm{P}>0.05)$ between treatments. Similarly, flows of all nitrogen fractions (TN, TNAN, SNAN, SPLPN and SSPFAAN) were not affected by the treatment $(\mathrm{P}>0.05)$ nevertheless duodenal flow of mentioned parameters tended to be higher when tablets $(\mathrm{T})$ were given.

Table 3. Duodenal flows of DM, nitrogen fractions and free amino acids, g/day

\begin{tabular}{|c|c|c|c|c|c|}
\hline \multirow{3}{*}{ Item } & \multicolumn{2}{|c|}{$\mathrm{C}$} & \multicolumn{2}{|c|}{$\mathrm{T}$} & \multirow{3}{*}{$\mathrm{P}$} \\
\hline & \multicolumn{2}{|c|}{$\mathrm{n}=6$} & \multicolumn{2}{|c|}{$\mathrm{n}=6$} & \\
\hline & mean & SEM & mean & SEM & \\
\hline \multicolumn{6}{|c|}{ Dry matter, total nitrogen and nitrogen fractions, g/day } \\
\hline DM & 8689.2 & 658.7 & 8848.6 & 224.9 & 0.816 \\
\hline $\mathrm{TN}^{1}$ & 328.3 & 20.8 & 343.0 & 10.7 & 0.526 \\
\hline TNAN $^{1}$ & 309.4 & 21.9 & 328.2 & 9.7 & 0.452 \\
\hline SNAN $^{1}$ & 114.4 & 8.6 & 122.6 & 2.8 & 0.292 \\
\hline SPLPN $^{1}$ & 5.2 & 2.5 & 5.4 & 2.1 & 0.945 \\
\hline SSPFAAN $^{1}$ & 109.1 & 6.8 & 117.2 & 2.2 & 0.275 \\
\hline \multicolumn{6}{|c|}{$\begin{array}{l}\text { Free amino acids, g/day } \\
\text { essential amino acids }\end{array}$} \\
\hline Arg & $0.15^{\mathrm{A}}$ & 0.03 & $0.37^{\mathrm{B}}$ & 0.12 & 0.009 \\
\hline His & $0.49^{\mathrm{A}}$ & 0.16 & $2.13^{\mathrm{B}}$ & 0.35 & 0.002 \\
\hline Ile & 0.07 & 0.01 & 0.11 & 0.02 & 0.177 \\
\hline Leu & $0.71^{\mathrm{a}}$ & 0.11 & $1.00^{\mathrm{b}}$ & 0.21 & 0.025 \\
\hline Lys & $0.76^{\mathrm{A}}$ & 0.12 & $2.07^{\mathrm{B}}$ & 0.33 & 0.003 \\
\hline Met & $0.35^{\mathrm{A}}$ & 0.08 & $1.25^{\mathrm{B}}$ & 0.24 & 0.002 \\
\hline Phe & 1.06 & 0.15 & 1.38 & 0.33 & 0.185 \\
\hline \multicolumn{6}{|c|}{ non-essential and endogenous amino acids } \\
\hline $\mathrm{GABA}^{2}$ & 1.45 & 0.20 & 1.69 & 0.46 & 0.566 \\
\hline Gly & 11.69 & 2.11 & 17.98 & 5.38 & 0.391 \\
\hline cysteic acid & 0.92 & 0.12 & 1.23 & 0.39 & 0.448 \\
\hline ornithine & 0.27 & 0.02 & 0.37 & 0.08 & 0.203 \\
\hline taurine & 1.57 & 0.36 & 3.46 & 1.26 & 0.175 \\
\hline Tyr & 1.08 & 0.17 & 1.39 & 0.32 & 0.050 \\
\hline
\end{tabular}

${ }_{\mathrm{a}, \mathrm{b}}$ means in the same row followed by the different superscripts $\operatorname{differ}(\mathrm{P}<0.05)$

$\mathrm{A}, \mathrm{B}$ means in the same row followed by the different superscripts differ $(\mathrm{P}<0.01)$

${ }^{1}$ see Table $1,{ }^{2}$ gamma aminobutyric acid 
Flow of Met, Lys and His used for the supplementation of soya protein was significantly higher $(\mathrm{P}<0.01)$ in the $\mathrm{T}$ group than in the control $(\mathrm{C})$. After usage of the rumen-protected tablets $(\mathrm{T})$ duodenal flow of Lys increased 2.7 times, Met 3.6 times and His 4.4 times in comparison with non-protected powder form. Flow of other two essential amino acids (Arg and Leu) in T group was significantly higher $(\mathrm{P}<0.01$ or $\mathrm{P}<0.05$, respectively) than in the control group C. Flows of Ile and Phe were not affected by the treatment.

The values of the duodenal flow of NEAA and endogenous AA (GABA, Gly, cysteic acid, ornithine, Tau and Tyr) did not differ significantly $(\mathrm{P}>0.05)$ between treatments but tended to be higher in the $\mathrm{T}$ group in comparison with the control $(\mathrm{C})$.

Because of the differences in DMI between experimental groups values of duodenal flows were converted according to DMI (Table 4) results were

Table 4. Duodenal flows of DM, nitrogen fractions and free amino acids converted according to dry matter intake

\begin{tabular}{|c|c|c|c|c|c|}
\hline \multirow{3}{*}{ Item } & \multicolumn{2}{|c|}{$\mathrm{C}$} & \multicolumn{2}{|c|}{$\mathrm{T}$} & \multirow{3}{*}{$\mathrm{P}$} \\
\hline & \multicolumn{2}{|c|}{$\mathrm{n}=6$} & \multicolumn{2}{|c|}{$\mathrm{n}=6$} & \\
\hline & mean & SEM & mean & SEM & \\
\hline \multicolumn{6}{|c|}{ Dry matter, total nitrogen and nitrogen fractions $\mathrm{g} /$ day $/ \mathrm{kg}$} \\
\hline DM & 565.96 & 34.97 & 571.12 & 16.82 & 0.904 \\
\hline $\mathrm{TN}^{1}$ & 21.39 & 1.01 & 22.13 & 0.69 & 0.584 \\
\hline TNAN $^{1}$ & 20.14 & 1.09 & 21.18 & 0.69 & 0.481 \\
\hline SNAN $^{1}$ & 7.44 & 0.44 & 7.92 & 0.26 & 0.396 \\
\hline SPLPN $^{1}$ & 0.33 & 0.15 & 0.34 & 0.13 & 0.887 \\
\hline SSPFAAN $^{1}$ & 7.12 & 0.36 & 7.58 & 0.26 & 0.398 \\
\hline
\end{tabular}

Free amino acids, $\mathrm{mg} /$ day $/ \mathrm{kg}$

essential amino acids

$\begin{array}{lcrrrr}\text { Arg } & 10^{\mathrm{a}} & 2 & 24^{\mathrm{b}} & 8 & 0.011 \\ \text { His } & 31^{\mathrm{A}} & 10 & 137^{\mathrm{B}} & 22 & 0.001 \\ \text { Ile } & 5 & 1 & 7 & 1 & 0.164 \\ \text { Leu } & 47 & 7 & 65 & 14 & 0.054 \\ \text { Lys } & 49^{\mathrm{A}} & 7 & 134^{\mathrm{B}} & 22 & 0.003 \\ \text { Met } & 22^{\mathrm{A}} & 5 & 81^{\mathrm{B}} & 15 & 0.001 \\ \text { Phe } & 69 & 10 & 90 & 23 & 0.265\end{array}$

non-essential and endogenous amino acids

\begin{tabular}{|c|c|c|c|c|c|}
\hline GABA $^{2}$ & 95 & 14 & 110 & 32 & 0.620 \\
\hline Gly & 761 & 136 & 1166 & 356 & 0.400 \\
\hline cysteic acid & 60 & 8 & 80 & 27 & 0.465 \\
\hline ornithine & 18 & 2 & 24 & 6 & 0.257 \\
\hline taurine & 103 & 24 & 221 & 76 & 0.162 \\
\hline Tyr & 71 & 12 & 91 & 22 & 0.149 \\
\hline
\end{tabular}

${ }^{a, b}$ means in the same row followed by the different superscripts differ $(\mathrm{P}<0.05)$

${ }^{\mathrm{A}, \mathrm{B}}$ means in the same row followed by the different superscripts $\operatorname{differ}(\mathrm{P}<0.01)$

${ }^{1}$ see Table $1,{ }^{2}$ gamma aminobutyric acid 
similar to unconverted ones. Duodenal flows of DM and nitrogen fractions (TN, TNAN, SNAN, SPLPN and SSPFAAN) were not significantly different between treatments $(\mathrm{P}>0.05)$. Conversion of flows according to DMI caused a lost of significance in the Leu flow $(\mathrm{P}>0.05)$ and a decrease of significance level $(\mathrm{P}<0.01$ to $\mathrm{P}<0.05)$ in the case of Arg. Converted flow of Met, Lys and His in T group was significantly higher $(\mathrm{P}<0.01)$ than in the $\mathrm{C}$ group.

\section{DISCUSSION}

The aim of this study was to confirm that the flow of soluble N-fractions and free amino acids through the duodenum increases after the addition of a ruminally protected soya protein enriched with Met, Lys and His in comparison with nonprotected powder form. In the present experiment the physical form of rumen protection, it is coating with the $\mathrm{pH}$ sensitive copolymer based on the patent of Ardaillon et al. (1989) was used. This technology provides a postruminal delivery system that is independent of digestive enzyme function and dependent on the differences in $\mathrm{pH}$ between the rumen and abomasum. It has been demonstrated (Schwab, 1995; Robert and Williams, 1997; Třináctý et al., 2006b) that the resulting ruminally inert products have an apparent high coefficient of rumen protection and posses high intestinal release coefficients of the coated substance. This technology used to protect supplemental Met appeared to be the most effective in increasing Met in metabolizable protein as evidenced by the largest increases in blood Met concentrations (Robert et al., 1997; Blum et al., 1999).

The intake of individual components from tablets $(\mathrm{T})$ or powder $(\mathrm{C})$ presented in Table 1 was identical in both groups. The same values for the both forms were assured in such a way that these two forms were exactly weighed according to content of active components and were applied directly to the rumen bottom of experimental animals through the ruminal cannula. Besides of added amino acids (Met, Lys and His) only intakes of $\mathrm{Arg}_{\mathrm{HP}}$ and $\mathrm{Lys}_{\mathrm{HP}}$ originating from soya bean protein HP 300 were mentioned because the daily intakes of the other major parts of FAA in HP 300 were very low ( $100 \mathrm{~g} /$ day).

Published results focused on the duodenal flow of soluble nitrogen fractions are scarce even there is no study of the effect of rumen-protected or unprotected form of ruminally supplemented soya-protein + Met, Lys and His on the duodenal flow of the soluble nitrogen fractions.

Values of DM flow are comparable with results obtained in an experiment with dairy cows with similar DMI (Robinson and Kennely, 1990). Duodenal flows of Arg and Leu in the $T$ group were significantly $(\mathrm{P}<0.05)$ higher. These results are correlated with a relatively high content of these amino acids in soya bean protein (Gonzáles et al., 2000). Due to the rumen protection of mixture duodenal flows of 
free Met, Lys, His and Arg increased by 3.6, 2.7, 4.4 and 2.5 times, respectively, against the control.

In dairy cows treated with tablets $(\mathrm{T})$ the intake of $\mathrm{DM}$ and other nutrients was higher $(\mathrm{P}<0.05)$ than with powder $(\mathrm{C})$. This fact was discussed earlier(Třináctý et al., 2006a). From the reason of the mentioned difference in DMI between experimental and control group values of duodenal flows were converted according to DMI. DM flow converted according to DMI can represent apparent DM digestibility expressed as an undigested part of DM. DM flow converted according to DMI was 571.12 and $565.96 \mathrm{~g} /$ day/kg DMI in group $\mathrm{T}$ and $\mathrm{C}$, respectively $(\mathrm{P}>0.05)$. These data are comparable with results of apparent DM digestibility obtained in an experiment with dairy cows with similar DMI (Robinson and Kennely, 1990).

If we compare intakes of supplemented amino acids (Met, Lys + Lys $_{\mathrm{HP}}$, His; Table 1) to their duodenal flows in the T group (Table 3), we can see apparently low effectivity of rumen protection (on average $22.5 \%$, ranged from 14.2 to $33.3 \%$ ). On the other hand increased protein and casein yield $(\mathrm{P}<0.05)$ in milk from dairy cows fed by ruminally protected tablets (Třináctý et al., 2006a) suggests that the real duodenal flow and availability of mentioned amino acids in this experiment were probably higher. Several possible mechanisms may contribute to the explanation of this discrepancy.

The protective layer of tablets used in the present experiment (vinyl-pyridine/ styrene copolymer; Ardaillon et al., 1989) was similar to those commercially used for rumen protection nevertheless our results are different from those published, e.g., by Robert and Williams (1997) for rumen protected methionine Smartamine ${ }^{\mathrm{TM}} \mathrm{M}$ (ranged from 75.0 to $97.1 \%$ ). Smartamine ${ }^{\mathrm{TM}} \mathrm{M}$ producer reports release of $90 \%$ of Met after $2 \mathrm{~h}$ incubation in $\mathrm{pH} 2$ buffer. However retention time of feed particles in abomasum can be shorter (Wylie et al., 2000) and that is why part of tablets could escape disintegration in abomasum. Retention time of large and heavy particles is shorter than that of digesta and shape of their passage curve is a narrow peak (Třináctý et al., 2005). In comparison with the Smartamine ${ }^{\mathrm{TM}}$ $\mathrm{M}$ (2 $\mathrm{mm}$ particles) the tablets were lenticular with the diameter of $6.5 \mathrm{~mm}$ and density of the tablet, 1.15 , is comparable with Smartamine ${ }^{\mathrm{TM}} \mathrm{M}$. From this reason part of whole tablets could escaped from sampling and their content was not included in analyses.

Generally, methods for evaluation of ruminally protected amino acid bioavailability using the duodenal sampling provide inaccurate results (Rulquin and Kowalczyk, 2003). The cows in the present experiment were fitted with the T cannulas (Komarek, 1981). Although T-cannulas are less disruptive to intestinal chyme flow than are most re-entrant cannulas major concerns with intestinal cannulation include intestinal dilation proximal to the fistula (Robinson et al., 1985), presumably resulting from deterioration of muscular and intestinal integrity, and excessive scar tissue development around the fistula. Intestinal 
dilation may result in digesta pooling, digesta stratification, and unrepresentative sampling.

Furthermore, other detectable FAA: gamma-aminobutyric acid (GABA), glycine (Gly), cysteic acid, ornithin, taurin and Tyr were classified among nonessential and endogenous amino acids. All these amino acids occurred in the supplemented soya protein only in traces and for that reason the metabolic processes are their main source. Taurin and Gly occur above all in bile as taurocholic and glychocholic acids and ornithin participates in the urea metabolism. Increased levels of these AA found in digesta suggest that the T-shaped duodenal cannulas were inserted approximately $60 \mathrm{~cm}$ distal to the pylorus, distal to the bile and pancreatic duct. Some deamination of AA may have taken place between the reticulum and the duodenal cannula. However, considerable amounts of AA may have been actively absorbed along the $60-\mathrm{cm}$ stretch between the abomasum and the site of the duodenal cannula.

For the verification of our presumption, that tablets escaped sampling with the contribution of the complex of mechanisms mentioned above, the recovery of marker (chromium oxide) in faeces was determined. We found out that the chromium recovery from faeces was $96.13 \%(\mathrm{SEM}=3.02, \mathrm{n}=12)$ which is in agreement with the results published by Hattan and Owen (1970). This finding together with the increase in milk protein and casein yield in T group (Trúnáctý et al., 2006a) suggests that ruminally protected tablets containing the soya protein enriched with the Met, Lys and His were functional.

\section{CONCLUSIONS}

This experiment confirmed the functionality of ruminally protected tablets containing amino-acid-supplemented soya protein by significant increase of duodenal flow of free amino acids: Met, Lys, His and Arg. However, probably because of escape of whole tablets from sampling process, balance between intake and real flow of added amino acids provided non-accurate results.

\section{ACKNOWLEDGEMENTS}

The authors gratefully thank to Ing. Stanislav Pavlok, Ing. Jiří Kotásek, Václav Hlaváček and Václav Havlíček for technical assistance. 


\section{REFERENCES}

AOAC, 1984. Association of Official Analytical Chemists, Official Methods of Analysis. 14 Edition. Washington, DC

Ardaillon P., Antant P., Bourrain P., Cartillier A., 1989. Compositions for coating feedstuff additives thus coated. United States Patent, US 4,877,621

Blum J.W., Bruckmaier R.M., Jans F., 1999. Rumen-protected methionine fed to dairy cows: bioavailability and effects on plasma amino acid pattern and plasma metabolite and insulin concentrations. J. Dairy Sci. 82, 1991-1998

Gonzáles J., Rodríguez C.A., Centeno C., Lamnari F., 2000. Rumen effective degradability of amino acids from soybean meal corrected for microbial contamination. Repod. Nutr. Develop. 40, 579-586

Hattan G.L., Owen F.G., 1970. Efficiency of total collection and chromic oxide techniques in shortterm digestion trials. J. Dairy Sci. 53, 325-329

Jarrige R., 1989. Ruminant Nutrition. Recommended Allowances and Feed Tables, INRA. John Libbey Eurotext Editions. Monrouge (France), pp. 389

Komarek R.J., 1981. Intestinal cannulation of cattle and sheep with T-shaped cannula designed for total digesta collection without externalising digesta flow. J. Anim. Sci. 53, 796-802

Licitra G., Hernandez T.M., Van Soest P.J., 1996. Standardization of procedures for nitrogen fractionation of ruminant feeds. Anim. Feed Sci. Tech. 57, 347-358

Ørskov E.R., McDonald I., 1979. The estimation of protein degradability in the rumen from incubation measurements weighted according to rate of passage. J. Agr. Sci. 92, 499-503

Robert J.C., Williams P.E.V., 1997. Influence of forage type on the intestinal availability of methionine from a rumen protected form. J. Dairy Sci. 80, Suppl. 1, 248 (Abstr.)

Robert J.C., Williams P.E.V., Bouza B., 1997. Influence of source of methoinine and protection technology on the postruminal delivery and supply to the blood of dairy cows of an oral supply of methionine. J. Dairy Sci. 80, Suppl. 1, 248 (Abstr.)

Robinson P.H., Kennely J.J., 1990. Evaluation of a duodenal cannula for dairy cattle. J. Dairy Sci. 73, 3146-3157

Robinson P.H., Smith D.F., Sniffen C.J., 1985. Development of a one-piece reentrant cannula for the proximal duodenum of dairy cows. J. Dairy Sci. 68, 986-994

Rulquin H., Kowalczyk J., 2003. Development of a method for measuring lysine and methionine bioavailibility in rumen-protected products for cattle. J. Anim. Feed Sci. 12, 465-474

Rulquin H., Vérité R., Guinard-Flament J., 2001a. Tables des Valeurs AADI des Aliments des Ruminants. INRA Prod. Anim. 14, Suppl., 16

Rulquin H., Vérité R., Guinard-Flament J., Pisulewski P. M., 2001b. Acides aminés digestibles dans l'intestin. Origines des variations chez les ruminants et répercussions sur les protéins du lait. INRA Prod. Anim. 14, 201-210

Russel J.B., O’Connor J.D., Fox D.G., Van Soest P.J., Sniffen C.J., 1992. A net carbohydrate and protein system for evaluating cattle diets: I. Ruminal fermentation. J. Anim. Sci. 70, 3551-3561

Schwab C.G., 1995. Protected proteins and amino acids. In: R.J. Wallace, A. Chesson (Editors). Biotechnology in Animal Feeds and Animal Feeding. V.C.H. Press, Weinheim (Germany), pp. 115-141

Schwab C.G., Bozak C.K., Whitehouse N.L., Olson V.M., 1992. Amino acid limitation and flow to the duodenum at four stages of lactation. 1. Sequence of lysine and methionine limitation. J. Dairy Sci. 75, 3486-3502

Sniffen C.J., O'Connor J.D., Van Soest P.J., Fox D.G., Russel J.B., 1992. A net carbohydrate and protein system for evaluating cattle diets: II. Carbohydrate and protein availability. J. Anim. Sci. $70,3562-3577$ 
Třináctý J., Kř̌́žová L., Hadrová S., Hanuš O., Janštová B., Vorlová L., Dračková M., 2006a. Effect of rumen-protected supplement with three amino acids on milk yield, composition and fatty acids profile in dairy cows. J. Anim. Feed Sci. 15, 3-15

Třináctý J., Richter M., Doležal P., Chládek G., Szakács J., 2006b. Function verification of ruminally protective layer of protein tablets. In: Proceedings of the 57th Annual Meeting of EAAP. Book of Abstracts. Antalya (Turkey), p. 322

Třináctý J., Richter M., Pozdíšek J., Kowalski Z. M., Fajmonová E., 2005. A comparison of passage parameters of nylon capsules and digesta calculated from faecal excretion data obtained in lactating cows. Czech J. Anim. Sci. 50, 450-458

Van Soest P.J., Robertson J.B., Lewis B.A., 1991. Methods for dietary fiber, neutral detergent fiber, and nonstarch polysaccharides in relation to animal nutrition. J. Dairy Sci. 74, 3583-3597

Volden H., Mydland L.T., Olaisen V., 2002. Apparent ruminal degradation and rumen escape of soluble nitrogen fractions in grass silage administered intraruminally to lactating dairy cows. J. Anim. Sci. 80, 2704-2716

Volden H., Velle W., Harstad O.M., Aulie A., Sjaastad O.V., 1998. Ruminal degradation and rumen escape of lysine methionine and threonine administered intraruminally in mixtures to highyielding cows. J. Anim. Sci. 76, 1232-1240

Williams C.H., David D.J., Iismaa O., 1962. The determination of chromic oxide in faeces samples by atomic absorption spectrophotometry. J. Agr. Sci. 59, 381-385

Wylie M.J., Ellis W.C., Matis J.H., Bailey E.M., James W.D., Beever D.E., 2000. The flow of forage particles and solutes through segments of the digestive tracts of cattle. Brit. J. Nutr. 83, 295-306 